\title{
EXAMINING INFORMATION TECHNOLOGY ACCEPTANCE BY INDIVIDUAL PROFESSIONALS
}

\author{
Licen Indahwati Darsono
}

\begin{abstract}
The mixed results of information technology (IT) investment have made the investigation of user acceptance of IT increasingly challenging. A growing body of research in user acceptance of IT literature has limitedfocus on individual professionals as target users. Therefore, this research investigates howexternal variables, namely individual differences and system characteristics influencelecturers as individual professionals to accept the internet technology. Technology Acceptance Model (TAM) and Theory of Planned Behavior $(T P B)$ are used as the main reference in this research. Findings of this research indicate that individual differences (computer self-efficacy, knowledge of search domain) and system characteristics (terminology, screen design, relevance) have indirect impact through perceived ease of use, perceived usefulness, and attitude on lecturers'intention to use the internet. Specifically, computer self-efficacy and screen design have direct and indirect impact on intention. One issue concerning with the explanatory power of the proposed research model, which is based on TAMand TPB, compared to the rival model, which is called extended TAM, is also analyzed.
\end{abstract}

Keywords: individual differences; system characteristics; TAM (Technology Acceptance Model), Theory of Planned Behavior (TPB); TRA (Theory of Reasoned Action) 
Gadjah Mada International Journal of Business, May-August 2005, Vol. 7, No. 2

\section{Introduction}

Rapidly advanced scientific and technological innovations, economic turbulence and uncertainty are some factors that underlie the importance of Information Technology (IT) investment. IT enables organizations to have the capabilities to do some adaptations proactively (Hartono 2003). As a result, IT becomes an integral part, even a pivotal part of business activities and processes undertaken by both profit and non-profit organizations (Hu et al. 1999). BPR (Business Process Reengineering), EDI (Electronic Data Interchange), and e-commerce are examples of IT application in profit organizations; while telemedicine ( $\mathrm{Hu}$ et al. 1999; Chau and $\mathrm{Hu}$ 2002), and digital libraries (Hong et al. 2002) are examples in non-profit organizations.

We have witnessed a wide array of IT applications implemented in various degree of success. Sircar et al. (2000) use sales, assets, and market value of the firm as indicators to measure the results of IT investment, and several organizations success, but others fail. It raises questions about the necessity to invest in IT. However, Agarwal and Karahanna (2000: 666) see this mixed results from different point of view. IT investment will be valueable if only when IT is utilized by their intended users in a manner that contributes to the strategic and operational goals of the firm. Thus, it is argue that user acceptance of IT is fundamental for successful IT investment.
Investigations of user IT acceptance are abundant in the information system literature. A review of relevant prior research suggests that fairly stream of technology acceptance studies are anchored in behavioral intention. According to the behavioralintention approach, individuals' decisions to accept a technology are a conscious act that can be sufficiently explained and therefore predicted by their behavioral intention (Chau and $\mathrm{Hu}$ 2002). Following this reasoning, it is challenging to identify crucial determinants of individuals' intention toward accepting IT. Technology Acceptance Model (TAM) is an established model in explaining information technology acceptance behavior. One key benefit of using TAM is that it provides a framework to investigate the impact of external variables on individuals' intention toward accepting IT. Individual differences and system characteristics have proven to have significant impacts on IT acceptance decisions (Hong et al. 2002), hence they will be used in this research as external variables.

The body of research about user IT acceptance is expanding into many areas that can be broadly categorized by applications (Harrison and Rainer 1992; Lim and Benbasat 2000; Venkatesh and Brown 2001) and target users (Igbaria et al. 1995; Hu et al.1999; Chau and Hu 2002; Hong et al. 2002). In target users categorization, research of user IT acceptance focuses on common user groups that typically include end users, knowl- 
edge workers, and managers at various levels. Most of them offer limited discussion on IT acceptance by individual proffesionals, except Hu et al. (1999), Chau and $\mathrm{Hu}$ (2002). Both of them target individual professionals, doctors, as users of IT. It motivates the author to use individual professionals, namely lecturers, as target users of IT acceptance. The reasons are lecturers also have specialized training, autonomous practices, and professional work arrangements in doing their jobs. Ideally, the internet technology can help lecturers to find new information and knowledge, to publish their research findings, to communicate with their peers and students. However, this idealistic sense seems not work in Indonesia; lecturers do not always accept the internet technology.

Curiosly, $\mathrm{Hu}$ et al. (1999) report that TAM has limited power to explain attitude and intention compared with prior studies examines TAM in a "nonprofessional" users. It may be caused by the differences between nonprofessional and professional users. Individual professional decisions to accept IT may differ from common users, in part because of specialized trainings, autonomous practices, and professional workarrangements (Chau and $\mathrm{Hu}$ 2002). Even though TAM is an established model in explaining user technology acceptance, Mathieson as cited by Igbaria et al. (1995) highlights "TPB provides more specific information on users' opinion about a system." In accordance with Mathieson (2001), Venkatesh and Brown (2001), propose that TPB (Theory of Planned Behavior) is an appropriate model for explaining volitional behavior. Intention to use and usage of IT by individual professional are volitional behavior, because of its inherent high degree of autonomy to use or not to use IT. The integration of TAM and TPB, therefore, encompasses the disadvantages of TAM, and this research will use it as a theoretical framework.

The basic purpose of this research is to investigate how external variables, namely individual differences and system characteristics affect lecturers as individual professionals to accept the internet technology. Further, this research compares explanatory power of research model that combines TAM and TPB with extended TAM model.

\section{Technology Acceptance Model}

TAM is developed by Davis to explain computer usage behavior $(\mathrm{Hu}$ et al. 1999). The theoretical ground for the model is Fishbein and Ajzen's Theory of Reasoned Action (TRA) (Hu et al. 1999; Hong et al. 2001). TRA postulates that beliefs influence attitudes, which in turn shapes a behavioral intention guiding, even dictating, individuals' behavior. Attitude is an overall evaluation about certain objects, or certain behavior, and it can be positive or negative (Assael 1998).

TAM shares with TRA the common thread that connects attitude to behavioral intention, but it differs con- 
Figure 1. Theory of Reasoned Action (TRA)

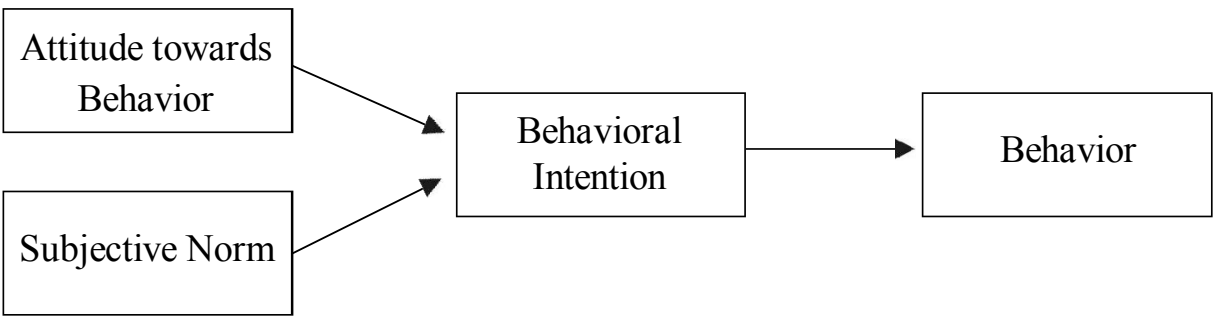

Source: Ajzen and Fishbein (1980) as cited by Dharmmesta (2002)

Figure 2. Technology Acceptance Model (TAM)

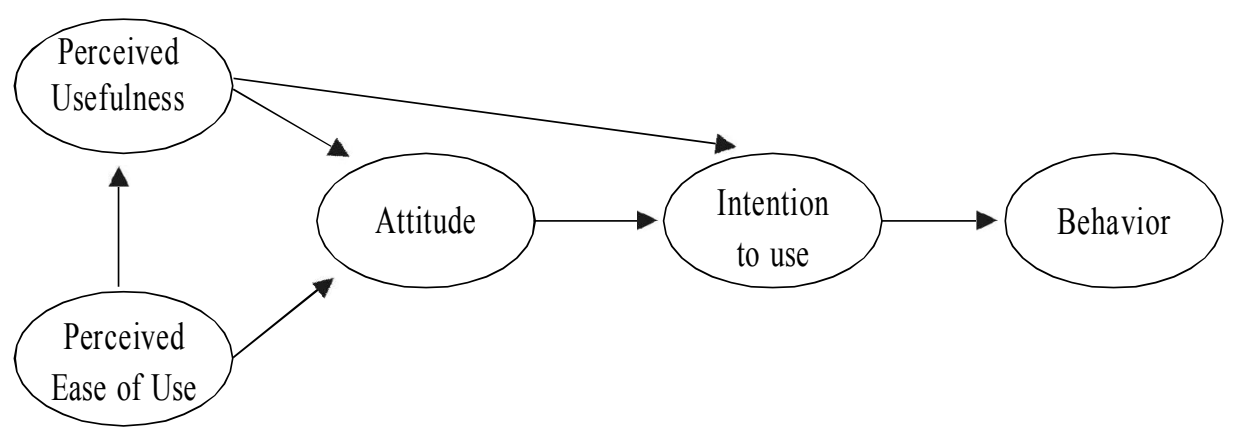

Source: Adapted from Hu et al. (1999)

siderably in the conceptualization of beliefs. There are two kinds of salient beliefs involved: perceived ease of use and perceived usefulness. Perceived usefulness is defined as the extent to which a person believes that using the system will enhance his job performance. Perceived ease of use is defined as the extent to which a person believes that using the system will be free of effort. According to TAM, behavioral intention is jointly determined by attitudes and perceived usefulness, altogether with perceived ease of use explain attitudes. Furthermore, both types of beliefs are subject to the influ- ence of external variables. (Hu et al. 1999; Hong et al. 2002; Chau and $\mathrm{Hu}$ 2002).

Saga and Zmud as cited by Hu et al. (1999) find that from prior $20 \mathrm{em}-$ pirical studies that aimed to investigate the nature and determinants of IT acceptance, TAM has advantages in parsimony, IT specificity, strong theoretical basis, and ample empirical support. However, TAM also has disadvantages:

1. TAM becomes problematic when it is specially geared to explain volitional behavior. Since lecturer's intention to use internet is volitional, 
Figure 3. Theory of Planed Behavior (TPB)

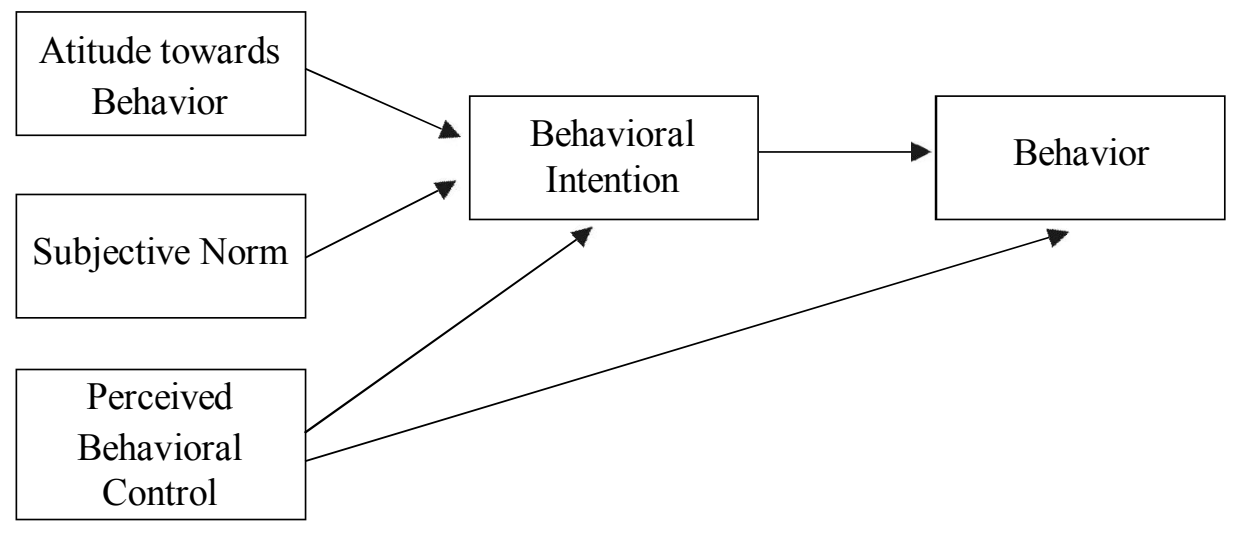

Source: Ajzen (1987) as cited by Dharmmesta (2002)

Venkatesh dan Brown (2001) argue that TPB is the proper model.

2. Mathieson as cited by Igbaria et al. (1995) compares TAM and TPB. He finds that TAM has a slight empirical advantage: it is simpler and easier to apply, but only supplies very general information on users' opinion about a system. It may be related with TRA, which is the generic theory for TAM. Bagozzi and Warshaw (1990) highlight that barriers to behave and outcomes from behavior are not considered in TRA. TPB provides more specific information that can better guide development.

As seen in Figure 3, TPB extends TRA by incorporating one additional construct, perceived behavioral control to account for situations where individuals lack of controls or resources necessary for carrying out the targeted behavior freely (Chau and $\mathrm{Hu} 2002$; Dharmmesta 2002).

\section{Research Model, Design, and Method}

\section{Research Model}

The proposed research model is based on the integration of TAM and TPB by incorporating perceived technology control. Prevalent dimensions of perceived technology control include acquisition of the procedural knowledge and resources necessary for mastering the technology under discussion. Perceived technology control is closely related but does not precisely correspond with the perceived behavioral control in TPB, which refers to an individual perception of the presence or absence of requisite resources or opportunities necessary for performing behavior (Chau and $\mathrm{Hu}$ 2002). It implies that perceived behavioral control has broader context than perceived technology control, and perceived tech- 
Gadjah Mada International Journal of Business, May-August 2005, Vol. 7, No. 2

Figure 4. Research Model

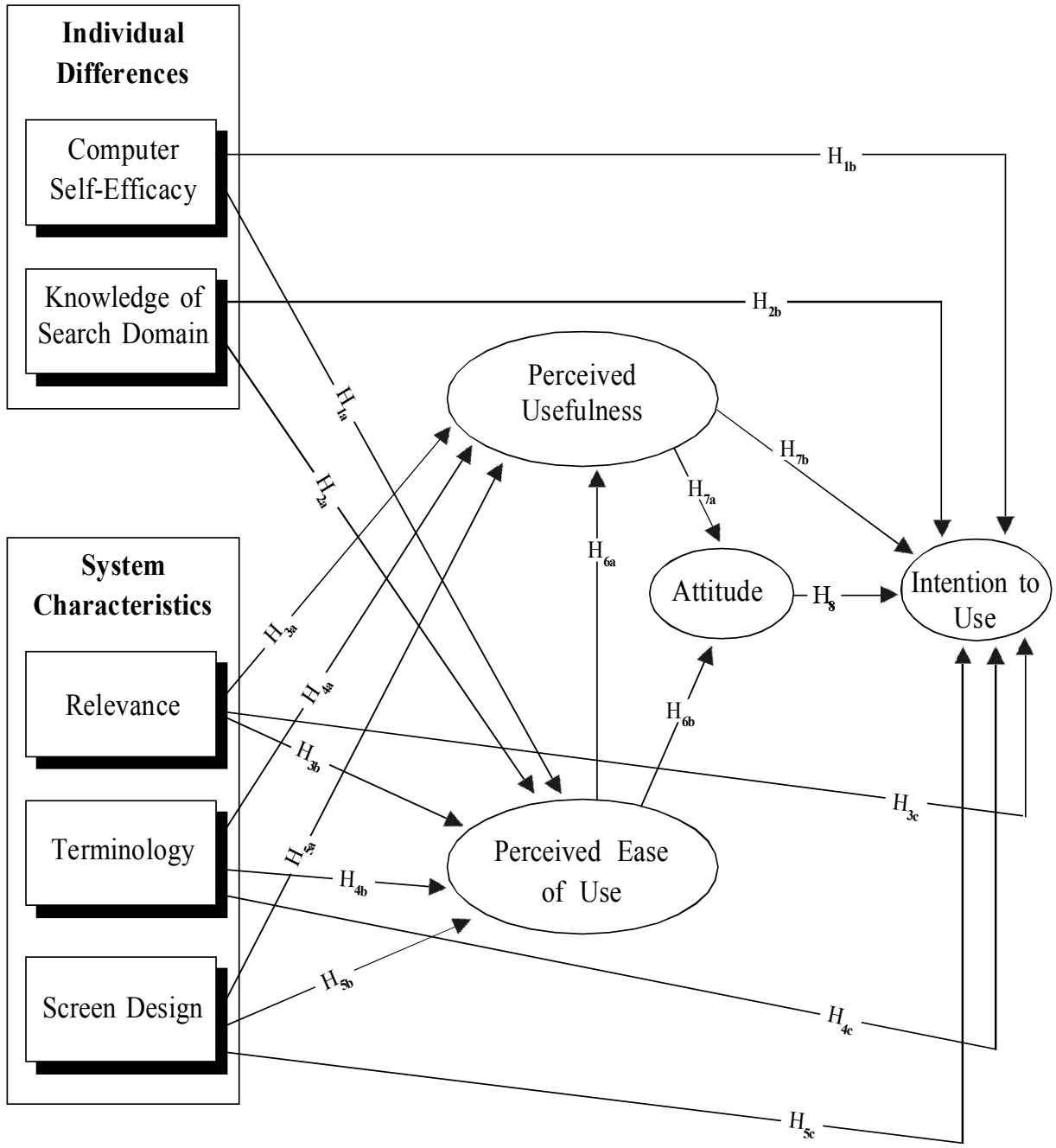

nology control refers to internal control inside individual, individual skill and willpower to use technology (Mathieson as cited by Hong et al. 2002). As a result, the notion of perceived technology control arguably is more relevant and specific than perceived behavioral control in investigations of IT acceptance decisions.
Lecturer's perceived technology control in this research is reflected by individual differences and system characteristics, regarding that individual differences and perception about systems generate lecturer perception about their capabilities to use it. Prior research also report that perceived technology control influences intention di- 
rectly or indirectly (Igbaria et al. 1999; Agarwal and Karahanna 2000; Chau and $\mathrm{Hu} 2002$ ). Thus, the author posits that individual differences and system characteristics as external variables directly or indirectly influence individual intention to use IT through perceived ease of use, perceived usefulness, and attitude (see Figure 4).

The author uses two variables of individual differences from Hong et al. (2002), computer self-efficacy and knowledge of search domain. Bandura as cited by Harrison and Rainer (1992: 102) defines self-efficacy as "an estimation of one's ability to perform target behaviors successfully." Computer self-efficacy, which is conceptualized based on self-efficacy theory, represents means individual evaluation about his or her capabilities to use computer (Hong et al. 2002). Lecturers with high degree of computer self-efficacy, are more likely to have high degree of perceived ease of use (Hong et al. 2002). Knowledge of search domain is individual knowledge about search domain (Hong et al. 2002). This knowledge helps individuals to classify relevant and irrelevant information. In this way, searching process becomes more impactive (Hong et al. 2002), and it leads to increased level of perceived ease of use.

$\mathrm{H}_{1 \mathrm{a}}$ :Computer self-efficacy has positive impact on perceived ease of use.

$\mathrm{H}_{1 \mathbf{b}}$ :Computer self-efficacy has positive impact on intention to use.
$\mathrm{H}_{2 \mathrm{a}}$ : Knowledge of search domain has positive impact on perceived ease of use.

$\mathrm{H}_{2 \mathrm{~b}}$ : Knowledge of search domain has positive impact on intention to use.

Moore and Benbasat as cited by Chau and $\mathrm{Hu}$ (2002) suggest that perceived rather than objective technology attributes more relevant to an individual's technology acceptance decision making. As a result, this research evaluates technology characteristics, reflected by system characteristics perceived by lecturers. System characteristics have the potential to directly affect both perceived ease of use and perceived usefulness (Igbaria et al. 1995; Lim and Benbasat 2000; Hong et al. 2002). The author uses three variables of system characteristics from Hong et al. (2002): terminology, relevance, and screen design. Terminology refers to the words, sentences, and abbreviations used by a system. (Liu et al. as cited by Hong et al. 2002). Lecturers' knowledge about terminology used by the internet technology can increase or decrease the potential benefits of the internet technology that can be provided to the lecturers. Therefore, it is expected that terminology has positive impact on perceived ease of use and perceived usefulness. Relevance is the degree to which the system matches tasks as carried out in the current environment and as specified in the task analysis (Hong et al. 2002). With respect to the 
Gadjah Mada International Journal of Business, May-August 2005, Vol. 7, No. 2

internet technology, it can be interpreted as the degree to which the internet technology fulfills lecturers information needs. If the internet technology have the capacities to give more relevant information, then lecturers feel that it is easier to find the information they need. Yao as cited by Hong et al. (2002) links relevance with usefulness by arguing that information will only be useful if users consider the information to be relevance. Therefore, it is hypothesized that relevance of the internet's content to lecturers' information needs is positively related to both perceived ease of use and perceived usefulness of the internet technology.

$\mathrm{H}_{3 \mathrm{a}}$ : The relevance of the internet technology as perceived by lecturers has positive impact on perceived usefulnes.

$\mathrm{H}_{3 \mathbf{b}}$ : The relevance of the internet technology as perceived by lecturers has positive impact on perceived ease of use.

$\mathrm{H}_{3 \mathrm{c}}$ : The relevance of the internet technology as perceived by lecturers has positive impact on intention.

$\mathrm{H}_{4 \mathrm{a}}$ : The knowledge about terminology of the internet technology as perceived by lecturers has positive impact on perceived usefulness.

$\mathrm{H}_{4 \mathbf{b}}$ : The knowledge about terminology of the internet technology as perceived by lecturers has positive impact on perceived ease of use.
$\mathrm{H}_{4 \mathrm{c}}$ : The knowledge about terminology of the internet technology as perceived by lecturers has positive impact on intention.

Screen design is the way information be presented on the screen (Liu et al. as cited by Hong et al. 2002). A good screen design can create a comfortable virtual environment where lecturers can easily identify functional groups and navigation aids, freely move around and scan search results, and make more efficient search. In turn, this efficient search leads to relevant information findings. Finally, lecturers are more likely to have higher degree of perceived ease of use and perceived usefulness. Therefore, it is expected that screen design has positive impact on perceived ease of use and perceived usefulness of the internet technology.

$\mathrm{H}_{5 \mathrm{a}}$ : The screen design of the internet technology as perceived by lecturers has positive impact on perceived usefulness.

$\mathrm{H}_{\mathbf{5}}$ : The screen design of the internet technology as perceived by lecturers has positive impact on perceived ease of use.

$\mathrm{H}_{5 \mathrm{c}}$ : The screen design of the internet technology as perceived by lecturers has positive impact on intention.

Prior research provides evidence of the significant impact of perceived ease of use on intention, either directly or indirectly through perceived usefulness and attitude ( $\mathrm{Hu}$ et al. 1999; 
Hong et al. 2002). In this vein, having a positive perception of a technology's ease of use may contribute to the development and solidification of a positive attitude toward using the technology, which in turn, can strengthen the intention for accepting the technology. Similarly, perceived ease of use may positively affect perceived usefulness (Hu et al. 1999; Hong et al. 2002; Chau and $\mathrm{Hu}$ 2002). Therefore, perceived ease of use has direct and indirect impact through perceived usefulness on attitude, and perceived usefulness has direct and indirect impact through attitude on intention ( $\mathrm{Hu}$ et al. 1999; Hong et al. 2002; Chau and $\mathrm{Hu}$ 2002).

$\mathrm{H}_{6 \mathrm{a}}$ :The level of perceived ease of use has positive impact on perceived usefulness.

$\mathrm{H}_{6 \mathbf{b}}$ : The level of perceived ease of use has positive impact on lecturers' attitude toward using internet.

$\mathrm{H}_{7 \mathrm{a}}$ :The level of perceived usefulness has positive impact on lecturers' attitude toward using internet.

$\mathrm{H}_{7 \mathbf{b}}$ : The level of perceived usefulness has positive impact on lecturers' intention to use internet.

$\mathrm{H}_{8}$ : Lecturers' attitude toward using internet has positive impact on lecturers' intention to use internet.

\section{Research Design}

\section{Sample}

The sampling frame of this research consists of all lecturers of
APTIK (Asosiasi Perguruan Tinggi Katolik) in Surabaya, Semarang, and Yogyakarta. Lecturers who are included as respondents in this research must be a full-time lecturer with the consideration that only a full-time lecturer have the likelihood to involve with the internet technology as well as becoming internet technology adopters in the future.

\section{Data Collection Procedure}

Data are collected by mail-survey, and 760 questionnaires are distributed to Unika Widya Mandala Surabaya, Universitas Atma Jaya Yogyakarta, Universitas Sanata Dharma Yogyakarta, and Unika Soegijopranata Semarang. Of the 760 questionnaires distributed, 364 questionnaires are returned. After careful examination, and excluding incomplete responses, monotonic answers, and outliers, only 300 responses are usable.

\section{Measures}

The question items used to operationalize the constructs are adapted from previous research, with several changes in wording in order to make them appropriate for the internet technology and lecturers education context. Specifically, 32 items on computer-self efficacy are adapted from Harrison and Rainer (1992); items on knowledge of search domain, terminology, screen design, relevance are adapted from Hong et al. (2002); items on perceived ease of use, perceived 
Gadjah Mada International Journal of Business, May-August 2005, Vol. 7, No. 2

usefulness, attitude, intention are adapted from $\mathrm{Hu}$ et al. (1999). All items are measured using a five-point Likert scale.

\section{Data Analysis and Results}

\section{Reliability}

Reliability is assessed using construct reliability and Cronbach's alpha. In order to achieve better reliability, six items from computer self-efficacy, two items from perceived usefulness, one item from attitude, and intention are deleted. Most of the investigated constructs exhibited a construct reliability and alpha values greater than 0.70 (see Table 1), suggesting a reliability exceeding the common acceptable level (Hair et al. 1998).

\section{Convergent and Discriminant Validity}

Generally, convergent validity is considered to be satisfactorily established when measurement items load highly on their respective constructs. Table 1 summarizes the results. Following Hair et al. (1998) recommendation, factor loadings greater than 0.40 is considered very significant. All of the factor loadings of the items in the research model are greater than 0.4 , with most of them above 0.60 . Each item loads significantly $(\mathrm{p}<0.01)$ in all cases on its underlying constructs. The average variances extracted of all constructs are above the recommended level 0.50 (Hair et al. 1998). In summary, the measurement model demonstrates adequate convergent validity.

Discriminant validity is evaluated by constrained correlation of two constructs, and followed by chi-square difference test between constrained and free model. If chi-square's values of free model lower than chi-square's values of constrained model, then discriminant validity is established, considering that lower chi-square indicates that the two contructs being estimated are not perfectly correlated $(\mathrm{Li}$

Table 1. Reliability Analysis

\begin{tabular}{lrrr}
\hline \multicolumn{1}{c}{ Constructs } & Item & Alpha \\
Computer self-efficacy & 31 & & 0.9573 \\
Knowledge of search domain & 2 & 0.8620 \\
Terminology & 2 & 0.8260 \\
Screen design & 2 & 0.8717 \\
Relevance & 2 & 0.8328 \\
Perceived ease of use & 5 & 0.8544 \\
Perceived usefulness & 4 & 0.9174 \\
Attitudes & 2 & 0.8539 \\
Intention & 5 & 0.9243 \\
\hline 164 & & \\
\hline
\end{tabular}


Darsono-Examining Information Technology Acceptance by IndividualProfessionals

\section{Table 2. Convergent Validity}

\begin{tabular}{|c|c|c|c|c|c|}
\hline Item & $\begin{array}{c}\text { Score } \\
\text { Efficacy }\end{array}$ & Control Variables & Item & $\begin{array}{c}\text { Score } \\
\text { Efficacy }\end{array}$ & Control Variables \\
\hline SE1 & 0.927 & & KS1 & 0.846 & Knowledge of \\
\hline SE2 & 0.937 & & $\mathrm{KS} 2$ & 0.873 & search domain \\
\hline SE3 & 0.755 & & & & \\
\hline SE4 & 0.840 & & $\mathrm{~T} 1$ & 0.887 & Terminology \\
\hline SE5 & 0.862 & & $\mathrm{~T} 2$ & 0.854 & \\
\hline SE6 & 0.897 & & & & \\
\hline SE7 & 0.929 & & SD1 & 0.882 & Screen \\
\hline SE8 & 0.909 & & SD2 & 0.857 & design \\
\hline SE9 & 0.919 & & & & \\
\hline SE10 & 0.886 & & $\mathrm{R} 1$ & 0.863 & Relevance \\
\hline SE11 & 0.864 & & $\mathrm{R} 2$ & 0.885 & \\
\hline SE12 & 0.884 & & & & \\
\hline SE13 & 0.964 & & PEOU1 & 0.784 & \\
\hline SE14 & 0.939 & & PEOU2 & 0.884 & Perceived ease \\
\hline SE15 & 0.832 & & PEOU3 & 0.806 & of use \\
\hline SE16 & 0.867 & Computer self & PEOU4 & 0.745 & \\
\hline SE17 & 0.819 & efficacy & PEOU5 & 0.859 & \\
\hline SE18 & 0.654 & & & & \\
\hline SE19 & 0.726 & & PU1 & 0.869 & Perceived \\
\hline SE20 & 0.752 & & PU3 & 0.861 & usefulness \\
\hline SE21 & 0.728 & & PU4 & 0.858 & \\
\hline SE22 & 0.715 & & PU5 & 0.917 & \\
\hline SE23 & 0.640 & & & & \\
\hline SE24 & 0.758 & & $\mathrm{~A} 1$ & 0.860 & Attitude \\
\hline SE25 & 0.668 & & A3 & 0.857 & \\
\hline SE26 & 0.727 & & & & \\
\hline SE28 & 0.718 & & I1 & 0.919 & \\
\hline SE29 & 0.503 & & I2 & 0.943 & \\
\hline SE30 & 0.945 & & I4 & 0.803 & Intention \\
\hline SE31 & 0.944 & & I5 & 0.865 & \\
\hline SE32 & 0.820 & & I6 & 0.924 & \\
\hline
\end{tabular}


Gadjah Mada International Journal of Business, May-August 2005, Vol. 7, No. 2

Table 3. Chi-Square Difference Test of Exogen Constructs

\begin{tabular}{|c|c|c|c|c|c|}
\hline Pair of Construct & $\begin{array}{c}\text { Chi- } \\
\text { Square } \\
\text { Free } \\
\text { Model }\end{array}$ & $\begin{array}{c}\text { Chi-Square } \\
\text { Constrained } \\
\text { Model }\end{array}$ & $\begin{array}{l}\text { Chi-Square } \\
\text { differences }\end{array}$ & $\begin{array}{c}\text { Degree } \\
\text { of Freedom } \\
\text { differences }\end{array}$ & Sig. \\
\hline $\begin{array}{l}\text { Computer Self-Efficacy and } \\
\text { Knowledge of Search Domain }\end{array}$ & 1150.750 & 1928.311 & 777.561 & 1 & .000 \\
\hline $\begin{array}{l}\text { Computer Self-Efficacy and } \\
\text { Terminology }\end{array}$ & 1133.432 & 2078.673 & 945.241 & 1 & .000 \\
\hline $\begin{array}{l}\text { Computer Self-Efficacy and } \\
\text { Screen Design }\end{array}$ & 1133.432 & 2078.673 & 945.241 & 1 & .000 \\
\hline $\begin{array}{l}\text { Computer Self-Efficacy and } \\
\text { Relevance }\end{array}$ & 1140.984 & 2085.725 & 944.741 & 1 & .000 \\
\hline $\begin{array}{l}\text { Knowledge of Search Domain and } \\
\text { Terminology }\end{array}$ & 0.906 & 100.978 & 100.072 & 1 & .000 \\
\hline $\begin{array}{l}\text { Knowledge of Search Domain and } \\
\text { Screen Design }\end{array}$ & 4.068 & 168.785 & 164.717 & 1 & .000 \\
\hline $\begin{array}{l}\text { Knowledge of Search Domain and } \\
\text { Relevance }\end{array}$ & 0.468 & 140.728 & 140.26 & 1 & .000 \\
\hline Terminology and Screen Design & 5.153 & 184.858 & 179.705 & 1 & .000 \\
\hline Terminology and Relevance & 5.420 & 205.072 & 199.652 & 1 & .000 \\
\hline Screen Design and Relevance & 0.457 & 186.753 & 186.296 & 1 & .000 \\
\hline
\end{tabular}

Table 4. Chi-Square Difference Test of Endogen Constructs

\begin{tabular}{|c|c|c|c|c|c|}
\hline Pair of Construct & $\begin{array}{c}\text { Chi- } \\
\text { Square } \\
\text { Free } \\
\text { Model }\end{array}$ & $\begin{array}{c}\text { Chi-Square } \\
\text { Constrained } \\
\text { Model }\end{array}$ & $\begin{array}{l}\text { Chi-Square } \\
\text { differences }\end{array}$ & $\begin{array}{c}\text { Degree } \\
\text { of Freedom } \\
\text { differences }\end{array}$ & Sig. \\
\hline $\begin{array}{l}\text { Perceived Ease of Use and } \\
\text { Perceived Usefulness }\end{array}$ & 151.964 & 275.474 & 123.51 & 1 & .000 \\
\hline $\begin{array}{l}\text { Perceived Ease of Use and } \\
\text { Attitude }\end{array}$ & 97.795 & 344.522 & 246.727 & 1 & .000 \\
\hline $\begin{array}{l}\text { Perceived Ease of Use and } \\
\text { Intention }\end{array}$ & 203.737 & 391.536 & 187.799 & 1 & .000 \\
\hline Perceived Usefulness and Attitude & 45.415 & 303.006 & 257.591 & 1 & .000 \\
\hline Perceived Usefulness and Intention & 142.304 & 315.300 & 172.996 & 1 & .000 \\
\hline Attitude and Intention & 114.467 & 441.231 & 326.724 & 1 & .000 \\
\hline
\end{tabular}


and Calantone 1998; Kenny 1998). Since there are five exogenous constructs and four endogeneous constructs, there are 10 pairs exogen constructs and 6 pairs endogen constructs evaluated. As summarized in Table 2 and 3, all pairs of construct of the free models have lower chi-square than constrained model, and the difference of its respective chi-square are statistically significant. In summary, the measurement model demonstrates adequate discriminant validity.

\section{Respondent's Profile}

Among the respondents, 52 percent of respondents are female and approximately 36 percent from eco-

Table 5. Respondent's Profile

\begin{tabular}{|c|c|c|c|}
\hline \multirow{2}{*}{$\begin{array}{l}\text { Subject } \\
\text { Sex: }\end{array}$} & \multirow[t]{2}{*}{ Percentage } & \multirow{2}{*}{$\frac{\text { Subject }}{\text { Faculty: }}$} & \multirow[t]{2}{*}{ Percentage } \\
\hline & & & \\
\hline -Male & 48 & - Technology of Industry & 0.3 \\
\hline \multirow[t]{2}{*}{-Female } & 52 & - Theology & 2 \\
\hline & & - MIPA (Science) & 1.7 \\
\hline University: & & -Pharmacy & 8 \\
\hline - Unika Widya Mandala, Surabaya & 30.3 & - Academy of Secretary & 2.3 \\
\hline -Unika Soegijapranata, Semarang & 26 & & \\
\hline - Atma Jaya, Yogyakarta & 14.3 & Working experience: & \\
\hline \multirow[t]{2}{*}{ - Universitas Sanata Dharma, Yogyakart } & 29.4 & - less than 2 years & 0.3 \\
\hline & & -2 until 5 years & 41.3 \\
\hline Faculty: & & -6 until 10 years & 35 \\
\hline - FKIP (Teacher Education) & 10 & - more than 10 years & 17 \\
\hline -Sastra(Literature) & 8 & & \\
\hline - Teknik (Engineering) & 13.7 & Age: & \\
\hline - Teknologi Pangan (Food Engineering) & 5 & - less than 25 years & 0.3 \\
\hline - Ekonomi (Economics) & 36 & - 25 until 34 years & 41.3 \\
\hline - Psikologi (Psychology) & 8.7 & - 35 until 44 years & 35 \\
\hline \multirow[t]{2}{*}{ - Hukum (Law) } & 4.3 & - 45 until 55 years & 17 \\
\hline & & - more than 55 years & 6.4 \\
\hline
\end{tabular}

nomics faculty, 33.3 percent fromUnika Widya Mandala Surabaya, 26 percent from Unika Soegijapranata, 14.3 percent from Universitas Atma Jaya Yogyakarta, and 29.3 percent from Universitas Sanata Dharma Yogyakarta. Most of them (48.3 percent) have working experience more than 10 years. The youngest respondent is 24 years old, and the oldest one is 75 years old, but most of them are around 25 and 34 years old. Curiously, as seen in Table 6, generally, older respondents, especially who are more than 55 years old, have lower computer self-efficacy and intention to use the internet than younger respondents. 
Gadjah Mada International Journal of Business, May-August 2005, Vol. 7, No. 2

Table 6. Cross Tabulation Results of Lecturer's Ages with Computer SelfEfficacy and Intention

\begin{tabular}{|c|c|c|c|c|c|c|}
\hline & & & & Ages & & \\
\hline & & $\begin{array}{c}<25 \\
\text { years }\end{array}$ & $\begin{array}{c}25-34 \\
\text { years }\end{array}$ & $\begin{array}{l}35-44 \\
\text { years }\end{array}$ & $\begin{array}{l}45-55 \\
\text { years }\end{array}$ & $\begin{array}{l}>55 \\
\text { years }\end{array}$ \\
\hline & Low & - & 1 & - & 1 & 1 \\
\hline Computer Self-Efficacy & Moderat & - & - & - & 1 & 1 \\
\hline & High & 25 & 123 & 105 & 49 & 17 \\
\hline & Low & - & 2 & 2 & 1 & 3 \\
\hline Intention & Moderat & - & 6 & 4 & 5 & 1 \\
\hline & High & 1 & 116 & 99 & 45 & 15 \\
\hline
\end{tabular}

\section{Results}

\section{Model Testing Results}

Results obtained from the structural equation modeling analysis suggest that the research model exhibits a quite satisfactory overall fit. Goodness of fit index (GFI) and comparative fit index $(\mathrm{CFI})$ values are exceeding recommended level 0.9 , but the values of adjusted goodness of fit index (AGFI), root mean square residual (RMSEA), normed chi-square(CMIN/ df) are slightly below recommended level (see Table 7).

The chi-square value is also large and significant. Model chi-square is the most common fit test, and its respective value should not be large and significant if there is a good model fit, while a significant chi-square indicates lack of satisfactory model fit. However, for model with more than
200 sample sizes, the chi-square is almost always statistically significant. Because of this reason, many researchers who use structural equation modeling believe that if other fit tests indicate good approximate fit, the significant of the chi-square test may be discounted and that significant chisquare is not a reason by itself to modify the model (Kenny 2002). Large and significant chi-square of the research model may be related with the sample size. The sample size of this research is more than 200. However, only two indices, GFI and CFI show good approximate fit, and two remaining indices, AGFI and RMSEA show marginal approximate fit. Therefore, it indicates a problem of goodness of fit, and it may become the weakness of this research. Thus, this study suggests the reader to interpret the results cautiously due to the weakness. 
Darsono-Examining Information Technology Acceptance by IndividualProfessionals

Table 7. Research Model Fit

\begin{tabular}{lccc}
\hline \multicolumn{1}{c}{ Indices } & $\begin{array}{c}\text { Recommended } \\
\text { Value (Hair et al. 1998) }\end{array}$ & Research Model \\
CMIN/DF & $<5$ & \\
GFI & $>0.9$ & 4.266 \\
AGFI & $>0.9$ & 0.975 \\
CFI & $>0.9$ & 0.857 \\
RMSEA & $<0.08$ & 0.883 \\
\hline
\end{tabular}

Figure 5. Hypothesis Testing Results

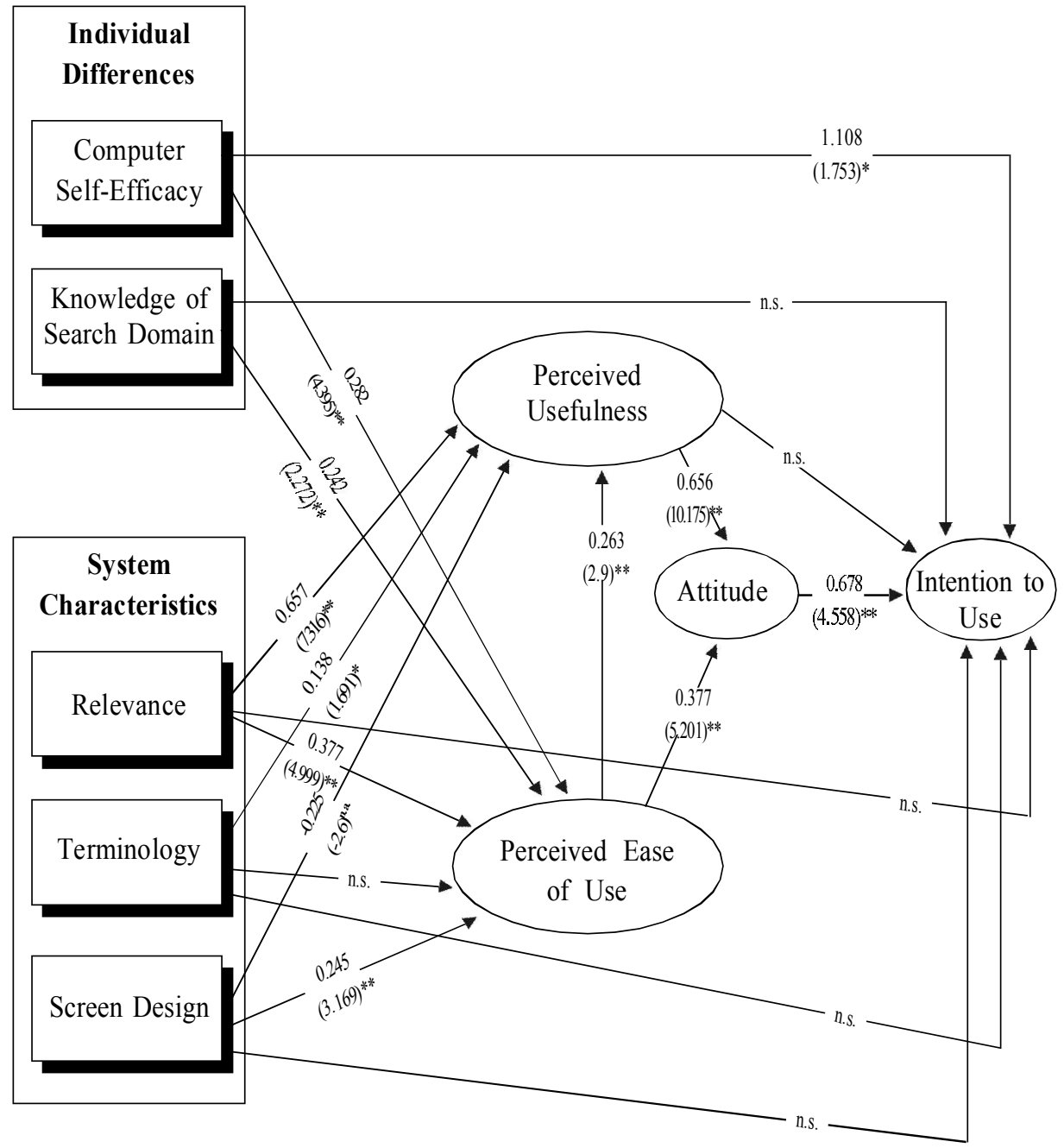

Notes: $*=\operatorname{sig}>0.05 ; * *=\operatorname{sig}>0.01 ;$ n.s. $=$ not significance; n.a. $=$ not applicable 
The results suggest that the model is able to explain 77.1 percent of the variances of lecturers' intention to use the internet technology (see Table 7). The significant and the relative strength of individual links specified by the research model are also evaluated. As seen in Figure 5, thirteen out of 18 postulated paths are of statistical significance; two at the 0.05 significtce level; nine at 0.01 level, and the remaining two at 0.001 level.

\section{Discussion}

Computer self-efficacy and knowledge of search domain have significant positive impact on perceived ease of use. It provides evidence that differences between lecturers positively affect perceived ease of use, and $\mathrm{H}_{1 \mathrm{a}}, \mathrm{H}_{2 \mathrm{a}}$ are supported. Relevance and screen design have significant positive impact on perceived ease of use, but the impact of terminology on perceived ease of use is not significant. As a result, $\mathrm{H}_{3 \mathrm{~b}}, \mathrm{H}_{5 \mathrm{~b}}$ are supported, and $\mathrm{H}_{4 \mathrm{~b}}$ is rejected.

The significant level of relevance on perceived usefulness is higher than other exogenous constructs with critical ratio 8.156. It reveals that lecturers' perception of the internet uselfulness is driven to a large extent by their perception of relevance of the internet technology. Terminology and perceived ease of use also have significant positive impact on perceived usefulness. Thus, $\mathrm{H}_{3 \mathrm{a}}, \mathrm{H}_{4 \mathrm{a}}$, and $\mathrm{H}_{6 \mathrm{a}}$ are supported. Curiously, screen design has negative significant impact on per- ceived usefulness. This study fails to find the possible reasons for this. With regard to this situation, the author concluded that screen design has no impact on perceived usefulness. Thus, $\mathrm{H}_{5 \mathrm{a}}$ is not supported in this research. Pararells with finding of this research, Hong et al. (2000) report the same results, with the exception for terminology, which is found has no significant impact on perceived usefulness.

Lecturers' perceived ease of use and its respective perceived usefulness have positive significant impact on lecturers' attitude toward using the internet technology, with its respective critical ratio, 3.719 and 10.829. It implies that $\mathrm{H}_{6 \mathrm{~b}}$ and $\mathrm{H}_{7 \mathrm{a}}$ are strongly supported. The critical ratio of perceived usefulness is greater than perceived ease of use. It reveals that the impact of perceived usefulness on attitude toward using the internet is stronger than the impact of perceived ease of use. There are two possible reasons for this. The first explanation is time. In the early stages of exploring the internet, perceived ease of use is the major determinant of using the internet. However, in the later stages of stable usage, when lecturers have accumulated experience with using the internet, the significant of perceived ease of use will decrease while the significant of perceived usefulness will increase. The second explanation is the characteristics of the target user in this research. With regard to lecturers' autonomy to use the internet, the likelihood of using the internet is predominantly affected by perceived usefulness. 
Darsono-Examining Information Technology Acceptance by IndividualProfessionals

Table 8. Research and Rival Model Comparation

\begin{tabular}{|c|c|c|}
\hline & $\begin{array}{c}\text { Research Model } \\
\text { (Integration of } \\
\text { TAM and TPB) }\end{array}$ & $\begin{array}{c}\text { Rival Model } \\
\text { (Extended TAM) }\end{array}$ \\
\hline \multicolumn{3}{|l|}{ Path: } \\
\hline Total path & 18 & 13 \\
\hline Sum of significance path & 12 & 10 \\
\hline Sum of not-significance path & 6 & 3 \\
\hline \multicolumn{3}{|l|}{ Direct Effects: } \\
\hline $\mathrm{SE} \rightarrow \mathrm{PEOU}$ & $0.282(4.395) * *$ & $0.295(4.522) * *$ \\
\hline $\mathrm{KS} \rightarrow \mathrm{PEOU}$ & $0.242(2.272) * *$ & $0.224(2.076) * *$ \\
\hline $\mathrm{T} \rightarrow \mathrm{PEOU}$ & $-0.158(-1.465)$ & $-0.172(-1.596)$ \\
\hline $\mathrm{SD} \rightarrow \mathrm{PEOU}$ & $0.245(3.169) * *$ & $0.247(3.153) * *$ \\
\hline $\mathrm{R} \rightarrow \mathrm{PEOU}$ & $0.377(4.99) * *$ & $0.397(5.161) * *$ \\
\hline $\mathrm{T} \rightarrow \mathrm{PU}$ & $0.138(1.691) *$ & $0.128(1.522)$ \\
\hline $\mathrm{SD} \rightarrow \mathrm{PU}$ & $-0.225(-2.609) * *$ & $-0.212(-2.418) * *$ \\
\hline $\mathrm{R} \rightarrow \mathrm{PU}$ & $0.657(7.316) * * *$ & $0.651(7.085) * * *$ \\
\hline $\mathrm{PEOU} \rightarrow \mathrm{PU}$ & $0.263(2.9) * *$ & $0.263(2.861) * *$ \\
\hline $\mathrm{PEOU} \rightarrow \mathrm{A}$ & $0.337(5.201) * *$ & $0.374(5.832) * *$ \\
\hline $\mathrm{PU} \rightarrow \mathrm{A}$ & $0.656(10.175) * * *$ & $0.632(9.824) * * *$ \\
\hline $\mathrm{SE} \rightarrow \mathrm{I}$ & $0.108(1.753) *$ & - \\
\hline $\mathrm{KS} \rightarrow \mathrm{I}$ & $-0.115(-1.130)$ & - \\
\hline $\mathrm{T} \rightarrow \mathrm{I}$ & $-0.128(-1.261)$ & - \\
\hline $\mathrm{SD} \rightarrow \mathrm{I}$ & $0.100(1.272)$ & - \\
\hline $\mathrm{R} \rightarrow \mathrm{I}$ & $0.149(1.462)$ & - \\
\hline $\mathrm{PU} \rightarrow \mathrm{I}$ & $0.098(0.673)$ & $0.110(0.850)$ \\
\hline $\mathrm{A} \rightarrow \mathrm{I}$ & $0.678(4.558) * *$ & $0.765(5.750) * *$ \\
\hline \multicolumn{3}{|l|}{ SMCs: } \\
\hline I & 0.745 & 0.748 \\
\hline \multicolumn{3}{|l|}{ Model Fit: } \\
\hline CMIN/DF & 4.266 & 3.297 \\
\hline GFI & 0.975 & 0.968 \\
\hline AGFI & 0.857 & 0.890 \\
\hline CFI & 0.883 & 0.866 \\
\hline RMSEA & 0.105 & 0.088 \\
\hline $\mathrm{AIC}$ & 108.126 & 106.867 \\
\hline
\end{tabular}

Notes:

( ) $=$ critical ratio

$*=\operatorname{sig}>0.05 ; * *=\operatorname{sig}>0.01 ; * * *=\operatorname{sig}>0.001$ 
Figure 6. Rival Model

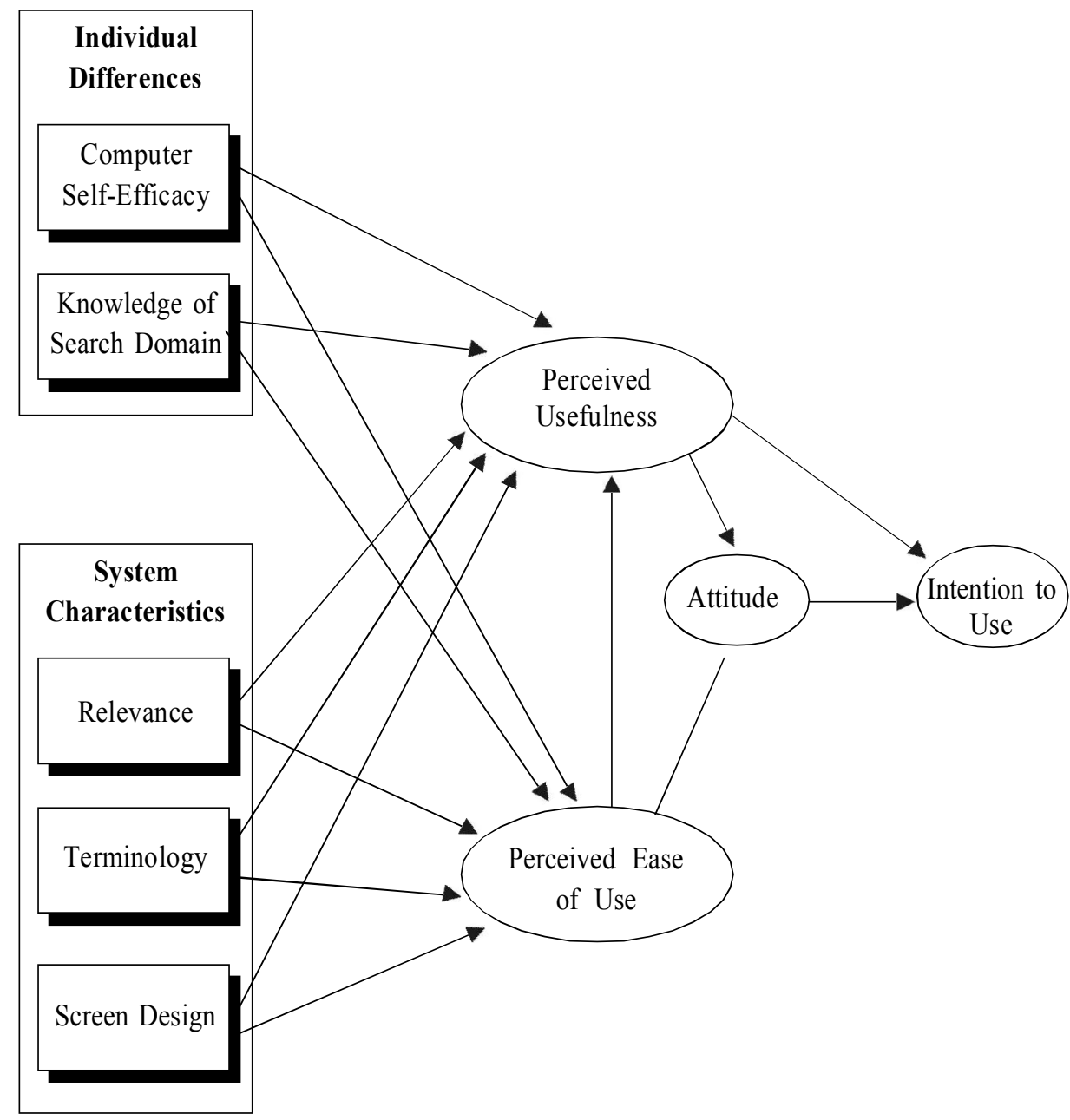

Computer self-efficacy and screen design have significant positive impact on intention. Knowledge of search domain and relevance are found to have insignificant impact on intention. Moreover, terminology has significant negative impact on intention, and this is not supported by theory. Thus, $\mathrm{H}_{1 \mathrm{c}}$ and $\mathrm{H}_{5 \mathrm{c}}$ are strongly supported, and $\mathrm{H}_{2 \mathfrak{c}}, \mathrm{H}_{3 \mathrm{c}}, \mathrm{H}_{4 \mathrm{c}}$, are rejected. The impact of computer self-efficacy on intention is much more significant than the impact of screen design. There are possible reasons for this. As summarized in Table 8, with the exception for relevance, the values of phi, Cramer's V, and contingency coefficient between computer self-efficacy and intention greater than the values of phi, Cramer's $\mathrm{V}$, and contingency coefficient between other exogenous variables and intention. However, after the association 
between relevance and intention is constrained with computer self-efficacy, its respective associations become not significant. These support the findings that the impact of relevance on intention is not significant. In addition, in the field works, the majority of respondents have perception that the primary prerequisite to use the internet is the ability to use computer.

This research reveals that perceived usefulness and lecturer's attitude toward the internet usage have positive significant impact on lecturers' intention to use the internet. These findings are in line with those of $\mathrm{Hu}$ et al. (1999) and Chau and $\mathrm{Hu}$ (2002). Thus, $\mathrm{H}_{7 \mathbf{b}}$ and $\mathrm{H}_{8}$ are strongly supported.

In order to compare the power of the research model with the rival model (see Figure 6), several indices of model fit must be evaluated (see Table 7). GFI, CFI, and AIC indices of the research model have better values than the rival model. The remaining three indices, CMIN/DF, AGFI, and RMSEA show that the rival model is better than the research model. However, if the result is cautiously seen, the differences of CMIN/DF, AGFI, RMSEA between the research and the rivalmodel $(1.059,0.037,0.017,0.016)$ are lower than differences of degree of freedom between the research and the rival model (5). More importantly, the chi-square differences are not statistically significant. In the chi-square table, at the significant level 0.2 and $\mathrm{df}$ $=5$, the chi-square's value is 7.289 , and the chi-square differences of the research and the rival model is 12.476 . Thus, the author suggests that the power of the research and the rival model is the same.

The capability of the research model to explain lecturers' intention to use the internet is 77.1 percent, slightly greater than the rival model, 76.2 percent. With respect to the sum of postulated path in each model, the research model has 18 paths, the rival model has 13 paths, the both model are concluded to have equal capability to explain lecturers' intention to use the internet. Thus, these findings verify previous study of Mathieson, which is reported that TAM and TPB has the same power to predict intention.

Several implications can be derived from these findings. TAM, TRA, and TPB have advantages and disadvantages. There is a trade-off between researcher's decisions to choose which one the researcher uses as the base model. TAM has several advantages, simple and easy, receives ample empirical supports, but the disadvantage of TAM is due to general information supplies. On the other hand, TPB gives more specific information, but it is more difficult to apply.

\section{Limitations and Implications for Further Research}

Large and significant chi-square, marginal approximate fit of AGFI and RMSEA indicate a problem of goodness of fit, and it may become the weakness of this research. Thus, the 
author suggests the readers to interpret the results cautiously due to the weakness.

Regarding to high average scores of every constructs, it can be suspected that social responsibility bias is probably happened. It may be related to majority of lecturers who have potential to be ashamed if they cannot and not willingly use the internet. Future research should test this researchmodel with other measures that encompasses social responsibility bias.

The advantage of research model (integration of TAM and TPB) over rival model (extended TAM) is the ability to give more specific explanation of lecturer's intention to use the internet, but it is more difficult to apply. However, both of them have equal explanatory power. There are possible reasons for this. It may be related with the absence of subjective norm in the research model. Even though previous study (Chau and $\mathrm{Hu} 2002$ ) reports that the impact of subjective norm is not significant, but there is setting differences within the research. Chau and Hu's (2002) study that was carried out in Hongkong, used doctors as target users. The subjective norms of doctors are doctors' promises and professional ethical codes of doctors, not the technology. This research is done in Indonesia, with lecturers as target users. Lecturers are expected to have cognitive capacity and more up to date information, especially in their major interest than others. Therefore, they need more information, and the internet is a powerful source of information. It im- plies that the capability to use the internet probably tends to be the subjective norm for lecturers in Indonesia. These possible reasons are supported by Ma'ruf et al. (2002). Ma'ruf et al. (2002) find the significant impact of subjective norm on intention to use the internet for shopping in Indonesia. Thus, the author stresses that the subjective norm must be considered as a predictor of intention in the future research.

\section{Conclusions and Managerial Implications}

Individual differences (computer self-efficacy and knowledge of search domain) and system characteristics (terminology, screen design, and relevance) are major determinants of lecturers' acceptance to the internet technology. Their impacts on intention are given directly or indirectly through perceived ease of use, perceived usefulness, and attitudes. However, in this research, only computer self-efficacy and screen design have positive significant direct impact on intention.

The integration of TAM and TPB has the same explanatory power with extended TAM. The advantage of the research model over the rival model is the ability to give more specific explanation of lecturers' intention to use the internet, but it is more difficult to apply.

Two managerial implications can be derived from this research. First, higher education management must consider academic staff readiness to 
use the internet technology, because computer self-efficacy predominantly influences intention to use the internet. More importantly, we must aware that computer is the underlying technology of the internet. Second, higher educa- tion management is also needed to train the academic staff to be skillful internet users since lecturers' perception of usefulness of the internet has impact on the intention to use the internet.

\section{References}

Adams, D. A., R. R. Nelson, and P. A. Todd. 1992. Perceived usefulness, ease of use, and usage of information technology: A replication. MIS Quarterly 16 (2): 227-247.

Agarwal, R., and E. Karahanna. 2000. Time flies when you're having fun: Cognitive absorption and beliefs about information technology Usage. MIS Quarterly 24 (4): 665-694.

Assael, H. 1998. Consumer Behavior and Marketing Action. ( $6^{\text {th }}$ ed.). Cincinnati, OH: South-Western College Publishing.

Bagozzi, R. P., and P.R. Warshaw. 1990. Trying to consume. Journal of Consumer Research 17: 127-140.

Chau, P.Y.K., and P. J. Hu. 2002. Examining a model of information technology acceptance by individual professionals: An exploratory study. Journal of Management Information System 18 (4): 191-229.

Dharmmesta, B. S. 2002. Trying to act: An empirical study of investigating higher education consumers. Gadjah Mada International Journal of Business 4(1): 45-66.

Hair, J. F., R. E. Anderson, R. L. Tatham, and W. C. Black. 1998. Multivariate Data Analysis ( $5^{\text {th }}$ ed.). Upper Saddle River, NJ: Prentice-Hall International, Inc.

Harrison, A. W., and R. K. Rainer. 1992. The influence of individual differences on skill in end-user computing. Journal of Management Information Systems 9 (1): 93-111.

Hong, W., J. Y. L. Thong, W. M. Wong, and K.Y. Tam. 2002. Determinants of user acceptance of digital libraries: An empirical examination of individual differences and system characteristics. Journal of Management Information Systems 18(3): 97124.

Hu, P. J., P. Y. K. Chau, O. R. Liu Sheng, and K. Y. Tam. 1999. Examining the technology acceptance model using physician acceptance of telemedicine technology. Journal of Management Information Systems 16 (2): 91-112.

Hartono, J. M. 2003. Sistem Teknologi Informasi. Pendekatan Terintegrasi: Konsep Dasar, Teknologi, Aplikasi, Pengembangan dan Pengelolaan. Yogyakarta: Andi Offset.

Igbaria, M., T. Guimaraes, and G. B. Davis. 1995. Testing the determinants of microcomputer usage via a structural equation model. Journal of Management Information Systems 11 (4): 87-114. 
Gadjah Mada International Journal of Business, May-August 2005, Vol. 7, No. 2

Kenny, D. A. 1998. Multiple factor models. URL: http://nw3.nai.net/ dakenny/ multiplefactormodel.htm.

2002. Measuring Model Fit. URL: http://nw3.nai.net/ dakenny/ measuringmodelfit.htm

Li, T. L., and R. J. Calantone. 1998. The impact of market knowledge competence on new product advantage: Conceptualization and empirical examination. Journal of Marketing 62 (3) (October): 13-29.

Lim, K. H., and I. Benbasat. 2000. The impact of multimedia on perceived equivocality and perceived usefulness of information systems. MIS Quarterly 24 (3): 449-471.

Ma'ruf, J. J., T. Ramayah, and O. Mohamed. 2002. Pengembangan model pengukuran untuk memprediksi perilaku niat menggunakan media internet: Suatu pendekatan struktural equation model. The Proceedings of the International Seminar, Indonesia-Malaysia: The Role of Harmonization of Economics and Business Discipline in Global Competitiveness. Banda Aceh, Indonesia.

Mathieson, K. 1991. Predicting user intentions: Comparing the technology acceptance model with the Theory of Planned Behavior. Information Systems Research 2 (3): 173-191.

Sircar, S., J. L. Turnbow, and B. Bordoloi. 2000. A Framework for asssesing the relationship between information technology investments and firm performance. Journal of Management Information System 17 (1): 69-71.

Venkatesh, V., and S. A. Brown. 2001. A longitudinal investigation of personal computers in homes: Adoption determinants and emerging challenges. MIS Quarterly 25 (1): 71-102. 
Computer Self-Efficacy

SE1 $=$ I feel confident entering and saving data into a file.

SE2 =I feel confident calling up a data file to view on the monitor screen.

SE3 =I feel confident storing software correctly.

SE4 =I feel confident handling a floopy disk correctly.

SE5 $=$ I feel confident escaping from a program or software.

SE6 =I feel confident making selections from an on screen menu.

SE7 $=$ I feel confident copying an individual file.

SE8 =I feel confident using the computer to write a letter or essay.

SE9 $=$ I feel confident moving the cursor around the monitor screen.

$\mathrm{SE} 10=\mathrm{I}$ feel confident working on a personal computer.

SE11 =I feel confident using a printer to make a "hardcopy" of my work.

SE12 $=$ I feel confident getting rid of files when they are no longer needed.

SE13 $=$ I feel confident copying a disk.

SE14 =I feel confident adding and deleting information from a data file.

SE15 $=$ I feel confident getting software up and running.

SE16 $=$ I feel confident organizing and managing file.

SE17 $=$ I feel confident understanding terms/words relating to computer software.

SE18 $=$ I feel confident understanding terms/words relating to computer hardware.*

SE19 $=$ I feel confident describing the function of computer hardware.

SE20 $=$ I feel confident troubleshooting computer problems. ${ }^{*}$

SE21 = I feel confident explaining why a program (software) will or will not run on a given computer.

SE22 $=\mathrm{I}$ feel confident understanding the three stages of data processing: input, processing, output.

SE23 =I feel confident learning to use a variety of program (software).*

SE24 =I feel confident using the computer to analyze a number of data.

SE25 $=$ I feel confident learning advanced skills within a specific program (software).*

SE26 $=$ I feel confident using the computer to organize information.

SE27 $=$ I feel confident writing simple programs for the computer.*

SE28 =I feel confident using the user's guide when help is needed.

SE29 =I feel confident getting help for problems in the computer system.*

$\mathrm{SE30}=\mathrm{I}$ feel confident logging onto a mainframe computer system.

SE31 $=$ I feel confident logging off the mainframe computer system.

SE32 $=$ I feel confident working on a mainframe computer.

Knowledge of Search Domain

KS1 $=\mathrm{I}$ am familiar with the subject domain that I search for on the internet.

KS2 $=\mathrm{I}$ am knowledgeable in the topic that I search for on the internet.

\section{Terminology}

T1 = I understand most of the terms used throughout the internet.

T2 =In my opinion, the use of terms thoughout the internet is consistent. 
Gadjah Mada International Journal of Business, May-August 2005, Vol. 7, No. 2

\section{Continued from APPENDIX (Questionnaires)}

\section{Screen Design}

SD1 $=$ The internet commands are well depicted by buttons and symbols.

$\mathrm{SD} 2=$ The layout of the internet screen is clear and consistent.

\section{Relevance}

R1 =Information resources in the internet relate well to my task.

R2 =The internet has enough information resources for supporting my task.

\section{Perceived Ease of Use}

PEOU1 = Learning to operate internet technology would not be easy for me.

PEOU2 = I would find it easy to get internet technology to do what I need to do as a lecturer.

PEOU3 $=$ My interaction with the internet technology would be clear and understandable.

PEOU4 $=$ It is not easy for me to become skillful in using internet technology.

PEOU5 $=$ I would find internet technology easy to use.

\section{Perceived Usefulness}

$\mathrm{PU}=1$ Using internet enable me to complete my duties as a lecturer more quickly.

PU2 = Using internet cannot improve my care to the student.*

PU3 $=$ Using internet can increase my productivity as a lecturer.

PU4 = Using internet can enhance my service effectiveness to the student.

PU5 $=$ Using internet can make my duties management as a lecturer easier.

PU6 = I feel that internet technology not useful for me as a lecturer.*

\section{Attitude}

A1 = Using internet technology for supporting my task as a lecturer is a good idea.

A2 = Using internet technology for supporting my task as a lecturer is unpleasant.*

A3 $=$ Using internet technology is very beneficial for me as a lecturer.

\section{Intention}

I1 = I intend to use internet technology in finishing my duties as a lecturer.

I2 = I intend to use internet technology in finishing my duties as a lecturer as often as needed.

I3 = I intend not to use internet technology in finishing my duties as a lecturer.*

I4 = Whenever possible, I intend to use internet technology in finishing my duties as a lecturer.

I5 = To the extent possible, I would use internet technology to do different things, tutorial, research, or public service.

I7 = To the extent possible, I would use internet technology in finishing my duties as a lecturer frequently.

Notes: $*$ ) $=$ items deleted 